\title{
Improving Science Processes Skills and Learning Outcomes of Junior High School Students on Problem Based Learning
}

\author{
Agapito da Costa Jerónimo ${ }^{1}$, Achmad Slamet ${ }^{2}$, YL Sukestiyarno ${ }^{3}$, Rusdarti ${ }^{4}$ \\ \{ bitobaticassa@yahoo.com¹; achsella@gmail.com²; sukestiyarno@gmail.com $^{3}$; \\ $\underline{\text { rusdarti@gmail.unnes.ac.id }{ }^{4}}$ 工 \\ Instituto de Ciências Religiosas “S. Tomás de Aquino” Díli, Rua de Paiol, Lahane-Ocidental, Díli, \\ Timor-Leste $^{1}$, Graduate School, Universitas Negeri Semarang, Indonesia ${ }^{2}$
}

\begin{abstract}
This study aims to improve the science process skills and student-learning outcomes with problem based learning management. This study used embedded experiments. The population of this study was Junior High School students, the samples taken specifically for students in studying Civic, Citizenship and Human Rights Education. Research variables are the skills of process science and learning outcomes. Data taken by observation and tests and processed by regression analysis, one sample t-test and gain test. The results showed that this learning scenario was able to raise the science process skills to achieve an average score of 77.98 , in a good category; the experimental class learning outcomes increased the average of $\mathrm{N}$-Gain to 0.61 in the medium category, while the control class was only 0.21 , in the low category. Based on the regression process science skills have a positive effect on learning achievement, by $72 \%$. Evidently, the experimental class learning achievement is better than the learning achievement of the control class. It can be concluded that the learning model by giving before face-to-face meetings, discuss exchanging knowledge, can strengthen the mastery of the concept of student learning achievement.
\end{abstract}

Keywords: scientific approach, problem solving, scientific process skills

\section{Introduction}

In step with the development of the demands of life in the 21 st century, education faced with a number of increasingly difficult challenges. One of them is that education must be able to produce human resources who have complete competence [1]. At least, four learning competencies must be mastered by students' namely high comprehension ability, critical thinking skills, the ability to collaborate and communicate, and the ability to think creatively [2].

However, it is based on observations during the learning process at the Junior High School in Dili (Timor-Leste) that students are not accustomed to thinking creatively and critically, not getting used to problem-based learning. To activate students, the teacher usually gives the assignments directly from the textbook and provides worksheets to students with assignments to summarize the material. Although the aim is to activate students and reduce expository methods, the main points are targeted material completely. Science process skills are skills that need to be installed, practiced, and possessed by students. These skills can be sharpen by getting 
students actively involved in solving problems that require the ability to think and act scientifically. This is the basis for scientific inquiry and intellectual development needed to learn science concepts [3]. The development of science process skills allows students to solve problems, think critically, make correct decisions, look for answers to problems, help students think logically, ask questions in a reasonable way and solve problems they face every day [4]]. Creative thinking, which needs to be emphasized in education, is important for individuals to be successful every time they face any problems later. In the teaching-learning process, it is needed that each individual, who with special individual and social abilities, can express themselves efficiently and can find similarities or differences from the problems they face and various solutions [5].

The scientific approach is used by teachers to make students fully involved in the learning process in achieving learning competencies from home. Learning does not only begin in the classroom, but through structured assignments, students are encouraged to make observations, ask questions, process and reason the concepts learned first [6]. The results of the scientific process are brought to class during the initial face-to-face meeting to carry out scientific elaboration with each other. Independent learning gives students the opportunity to solve problems both with friends and other people outside the classroom. At face-to-face students can elaborate learning and work in teams and collaborations to develop cognitive processes that are useful for researching the environment, understanding problems, taking and analyzing important data, and elaborating solutions [7]. Next with the teacher doing problem solving as confirmation the science he has learned. The steps of problem-based learning are understanding problems, making plans, implementing plans, and looking back [8]. Through these steps it is expected to develop science process skills and ultimately be able to improve student learning outcomes. This study was programmed aimed at improving science process skills with problem based learning management to optimize student learning outcomes. This can be implemented optimally, effectively and efficiently if supported by management in the scientific learning process [9].

Management of scientific learning is the activity of management of the learning process to achieve learning goals through interaction between learners, educators and learning resources in the learning environment [10] which includes three stages of scientific learning management consisting of planning, implementation, and supervision [11].

The steps for problem-based learning understand problems, making plans, implementing plans, and giving feedback [12]. Through these steps, it is expected to develop science process skills and ultimately be able to improve the student-learning outcomes. Although this problembased scientific learning approach is very effective for use in the learning process, it also has weaknesses. One of the disadvantages of learning with this problem-based scientific approach is the process steps that must be taken cannot be completed in just one meeting [13]. To overcome this weakness, observation activities can be carried out outside the classroom in the context of homework, certainly with careful planning by the teacher and students.

Based on the above description, the problem raised is whether the implementation of problem-based scientific learning approaches can develop students' science process skills and improve student learning outcomes? With this research problem, the purpose of this study is to determine the development of science process skills and learning outcomes of Junior High School students in the City of Dili (Timor-Leste) by using scientific approach with problembased learning management. 


\section{Method}

This study used a design with an embedded experimental model [14]. The scope of this research is learning material in Civic, Citizenship and Human Rights Education. The study population was junior high school students in Timor Leste. Samples conducted by purposive sampling, namely by taking the experimental class and the control class. Research variables are process science skills as independent variables and dependent variables are learning outcomes. Process variable skill indicators include: observation, formulating questions, problems, data, classifying and analyzing data, formulating conclusions, and predicting results. While indicators of learning achievement are basic competencies as outlined in the syllabus and data taken by observation and tests. Data processed by regression analysis to see the effect of process science skills on learning achievement, one sample t-test to measure student learning completeness and gain test to see improvement in learning outcomes from pre and posttests.

\section{Result and Discussion}

The learning acitivities in this study are, in priciple, based on the lesson plans taht have been developed, wich apply problem-based learning applied to VIII grade in the Junior High Schools in Dili (Timor-Leste), for the subject Civic, Citizenship and Human Rights Education. The aspects of science process skills developed in problem-based learning are observation, formulating questions, formulating hypotheses, making observations of problems, collecting data, classifying and analyzing data, making conclusions, communicating, and applying concepts or making predictions. The results of the development of aspects of science process skills as shown in Table 1 below:

Table 1. Average Value of Students Science Process Skills (SPS)

\begin{tabular}{|c|c|c|}
\hline SPS Aspect & SPS Average Value & Category \\
\hline Observation & 85.00 & Very good \\
\hline Formulating Questions & 81.50 & Very good \\
\hline Formulating Problems & 75.00 & Good \\
\hline Observation of Problems & 85.00 & Very good \\
\hline Creating Data & 75.00 & Good \\
\hline Classifying and Analyzing Data & 74.00 & Good \\
\hline Formulating Conclusions & 73.50 & Good \\
\hline Communicate & 81.30 & Very good \\
\hline Apply the Concepts and Making Predictions & 72.00 & Good \\
\hline Average & 77.98 & Good \\
\hline
\end{tabular}

Based on Table 1, in general, the average score of science process skills in the good category is equal to 77.98. This development is seen in two classifications of categories namely the Very Good and the Good Category. The very good categories are in five aspects, namely: observation; formulate questions; observation of problems; recording data; and delivery. While the Criteria with Good Categories found in four other aspects, namely: formulating a problem; organizing data; formulate conclusions; and apply concepts/ predictions. 
Improving student learning outcomes is measured using posttest. The results of the data analysis of the average score of the pretest and posttest of the test results are presented in Table 2 bellow:

Table 2. Results of comparison of pretest and posttest scores of Learning Outcomes

\begin{tabular}{lccc}
\hline Class & Pre-Test & Post-Test & $\begin{array}{l}\text { N-Gain Average } \\
\text { Score }\end{array}$ \\
\hline Experimental & 62.24 & 85.12 & 0.61 \\
Control & 61.76 & 67.4 & 0.21 \\
\hline
\end{tabular}

Based on Table 2, in general, the achievement of student learning, both in the experimental class and the control class has increased, but the increase in the experimental class is better than the control class, where the average $\mathrm{N}$-gain score increases by 0.61 which is in the medium category. While increasing the average $\mathrm{N}$-gain score of the control class only reached 0.21 in the Low Category. So increasing the experimental class is better than the control class.

The results of science process skills of students with problem-based scientific learning get good results (satisfying). Likewise, student learning outcomes after learning are achieved achieving a high average score. Judging from the influence of process skill variable science (x) on post test learning achievement $(y)$, regression equation obtained $y=3.3+0.456 \mathrm{x}$, and the contribution is $72 \%$. This means that the struggle to bring students to the learning can bring skilled learning students and have a positive effect on the acquisition of learning achievements.

These findings are influenced by activities in the implementation of a scientific approach that involves the active role of students. This method is most effective in describing the concepts learned by aligning themselves as much as possible with reality [15]. However, from the table it can be seen and should be recognized that there are some aspects that have not been maximized, such as aspects of formulating problems; aspects of applying concepts and making predictions; aspects of classifying and analyzing data; and aspects of making data. Expectedly, this is due to the level of intellectual development of students who are not yet adequate.

From the results of the study as described above, it can be believed that problem-based learning methods can also improve students' ability to solve problems. This hypothesis is supported by the results of research that suggest learning outcomes with problem posing and creative problem solving can make problem-solving abilities better than other class students who use expository methods [16]. Learning with this model can make learning into meaningful learning. Because with this approach, the students no longer memorize the material learned, but the material learned is understood in a meaningful and efficient manner. Meaningful learning can occur if it is relevant to the needs of students, accompanied by intrinsic motivation and a rigid curriculum. The meaningful learning events are driven by the desire and intensity of learners' curiosity about a particular field of study. Learning is meaningfully related to Vygotsky's constructivism theory that students construct knowledge or create meaning as a result of thinking and interacting in a social context based on the knowledge they already have [17]. In problem-based learning new information found is associated with the understanding structure that students already have [18]. The students will be more assisted if the problems or cases studied are concrete cases and trends that occur in the community or student environment; because this will be more interesting so they are motivated to investigate it.

The results of this study are in line with the results of the study [19] which revealed that problem based learning can develop science process skills and problem solving abilities. The results of the study also note that the application of problem-based learning approaches has a significant influence on improving students' creativity and communication skills [20]. These 
findings are supported by the opinion Fahrudin and Usman [21] that problem-based learning is considered successful when students are not reminders of information, but when they know the important information they have, what is the relationship with the information, and how to use it to make changes. This is in line with the new education paradigm that education is essentially education for life. This means that the knowledge and skills acquired by students in schools must be truly usable to face the demands of life and solve life problems that they encounter.

The problem-based learning process can develop science process skills and make student learning outcomes to the maximum if the teacher can accept students as they are; recognize and nurture students through their discovery of themselves; provide learning resources namely problems or real or concrete cases that can be selected and used by students to be observed; seek inquiry-discovery so that a process of finding and finding new information occurs; let students take their own responsibility to fulfill their learning goals. So in this learning model the teacher only acts as a learning facilitator, students who are more active in the learning process, studentcentered learning.

There are two main activities developed in learning with this problem-based scientific approach, namely exploration activities and elaboration and confirmation activities. Exploration activities are carried out through observation activities carried out at home or outside of school, both individually and in groups based on preparations or plans that have been prepared with the teacher and students at the end of the lesson at the last meeting of the previous week. In the preparation or plan, it has been clearly defined the object or case that must be observed, the information that must be collected, sources of information; how to obtain these information, and the tools needed. The observing objects or cases are concrete cases easily to obtain but relevant to the learning material. Elaboration and confirmation activities are done in class with the teacher. The results of observations made at home or outside the class then taken into the classroom to be discussed and explored together through discussion or other appropriate techniques under the guidance of the teacher. In this way, the students come to school no longer empty but have pocketed some information to develop. In addition, the available time allocation is really utilized to the fullest.

\section{Conclusion}

The application of learning with a problem-based scientific approach can make students' science process skills develop in each phase consisting of making observations, formulating hypotheses, making experiments, making data, classifying and analyzing data, form conclusions, communicate, and apply concepts and make predictions with the acquisition of an average value of 77.98, in good categories. In addition, problem-based learning methods can also improve the student learning outcomes better than students who use conventional methods. In the experimental group the average $\mathrm{N}$-Gain increase reached 0.61 in the medium category, while in the control class the average N-Gain increase was only 0.21 in the low category. Science process skills of students have a positive effect on learning achievement by $72 \%$. Thus, it can be concluded that the scientific learning approach with Problem Based Learning method can be used as an alternative learning method, because this method is proven able to efficiently optimize science process skills and improve the student-learning outcomes. This means that using concrete life problems in learning students are encouraged to learn in a different and interesting atmosphere so that they are enthusiastic and active in learning, thereby optimizing the achievement of student learning. 



\section{References}

[1] Abidin, Y. Desain Sisem Pembelajaran dalam Konteks Kurikulum 2013. p. 8, Bandung: PT Refika Aditama, (2014).

[2] Marocco, C.C. Supported Literacy for Adolescents: Transforming Teaching and Content Learning for Twenty-First Century. p.5, San Fracisco-USA: Jossey-Bass A Wilery Imprint, (2008).

[3] Duran, M., et al. "The Relationship Between The Pre-Service Science Teachers' Scientific Process Skills And Learning Style,” J. Educ. Sci., pp. 467-476, (2011).

[4] Simsek, P. and Kabapnar, F. "The effects of inquiry-based learning on elementary students ' conceptual understanding of matter , scientific process skills and science attitudes," Procedia, vol. 2, pp. 1190-1194, 2010.

[5] Ersoy, E. and Başer, N. "The Effects of Problem-based Learning Method in Higher Education on Creative Thinking,” Procedia - Soc. Behav. Sci., vol. 116, pp. 3494-3498, (2014.

[6] Sumantri, M. S. Strategi Pembelajaran: Teori dan Praktik di Tingkat Pendidikan Dasar. p. 205, Jakarta: PT Raja Grafindo Persada, 2015.

[7] Rusman. Belajar \& Pembelajaran Berorientasi Standar Proses Pendidikan. p. 345, Edisi Pert. Jakarta: Kencana, (2017)

[8] Majid, A. and Rochman, C. Pendekatan Ilmiah dalam Implementasi Kurikulum 2013. Bandung: PT Remaja Rosdakarya, (2014).

[9] Mansur, N. "Meningkatkan Mutu Pendidikan Melalui Penerapan Manajemen Berbasis Sekolah," J. Ilm. Didakt., vol. XIV, no. 1, pp. 24-42, (2013).

[10] Nirwana. "Pengaruh Manajemen Lingkungan Dan Gaya Kognitif Terhadap Hasil Belajar IPAFisika di SMPN Kota Bengkulu (Studi eksperimen pada siswa kelas VII Semester I SMPN 11 Kota Bengkulu) 2012,” FKIP Univ. Bengkulu, no. 3, pp. 71-79, (2012).

[11] Terry, G. R. Asas - Asas Manajemen Edisi Kedelapan. Terjemahan Winardi. Bandung: PT Alumni, (2012).

[12] Saeroji, A., Slamet, A. and Khafid, M. "Scientific Learning Approach on Subject Material Computer Application for Financial Administration," UNNES J. Econ. Educ., vol. 7, no. 2, pp. 10-17, (2018).

[13] Narsim, Slament, A. and Kardoyo, "Pengembangan Model Discovery Learning dalam Pembelajaran Reading di SMA Negeri 1 Jeruklegi Cilacap," Educ. Manag. Major Themes Educ., vol. 5, no. 1, pp. 1-1813, (2016).

[14] Creswell,J. W. Research Design. Yogyakarta: Pustaka Pelajar, (2013).

[15] Rusman. Model-model Pembelajaran: Mengembangkan Profesionaisme Guru. p. 245, Edisi kedu. Bandung: PT Raja Grafindo Persada, (2012).

[16] Taryadi and Rusdarti, "Problem-Based Learning Method Using Comic As A Medium Toward Students' Learning Outcomes Of Economy Social Science in Uang dan Lembaga Keuangan," UNNES J. Econ. Educ., vol. 7, no. 1, pp. 1-9, (2018).

[17] Schunk, D. H. Learning Theories: An Educational Perspective, Edisi ke-6. Yogyakarta: Pustaka Pelajar. pp. 580-583, (2012).

[18] Rustaman, N. Y. "Penilaian Otentik (Authentic Assessment) dan Penerapannya dalam Pendidikan Sains". pp. 1-18, (2015).

[19] Wahyuni, S. and Suana,W. "Developing Science Process Skills and Problem-Solving Abilities Based on Outdoor Learning in Junior High School," UNNES J. Pendidik. IPA Indones., vol. 6, pp. 165-169, 2017.

[20] Muharromi, D. S. and Sa'ud, U. S. "Effect of Problem Based Learning Application In Increasing Creativity and Ability Young Learners," Edutech, vol. 15, pp. 21-38, (2016).

[21] [21] Fahruddin and Usman. "Caracter Building Evaluation Model of Dialogical Learning at Qaryah Thaiybah Alternative .chool in Kalibening Salatiga Indoensia," Medwell Jurnals, vol. 11, no. 22, pp. 5333-5337, (2016). 